\title{
The effect of climatic change on the rheological properties of winter wheat doughs
}

\author{
Norbert Boros ${ }^{1,2}$-Éva Kónya ${ }^{1}$ - Sándor Fórián ${ }^{2}$ - Zoltán Győri ${ }^{1}$ \\ ${ }^{1}$ Institute of Food Science, Quality Assurance and Microbiology, Faculty of Agronomy, University of Debrecen, 138. Böszörményi Str. H- \\ 4032 Debrecen, Hungary \\ ${ }^{2}$ Department of Chemical and Environmental Engineering, Faculty of Engineering, University of Debrecen, 2-4. Ótemetõ Str. H-4028 \\ Debrecen, Hungary \\ norbert.boros@hotmail.com
}

\section{SUMMARY}

\begin{abstract}
In present paper we have examined the effect of climatic change on the extensigraph characteristics of wheat-flours. The baking quality of winter wheat is largely determined by cultivar, but it can be influenced by weather conditions during growing period. Flours were from 5 cultivars grown at one location in three cropping years. We have found that the extensigraph properties of dough are affected by the weather conditions, nevertheless, different cultivars distinctly react to the increase of temperature and decrease of precipitation. In generally, the higher average day temperature and lower precipitation level is favourable to produce winter wheat flour with better quality.
\end{abstract}

Keywords: rheological properties, winter wheat, weather conditions, climatic change

\section{INTRODUCTION}

The rheological characteristics of doughs are determined by the amount and proportion of gliadin and glutenin proteins, and their significance lies in the fact that they affect both the processing ability of the dough and the quality of the end product.

Probably the most significant factor in determining the baking quality of winter wheat is the variety, as it primarily accounts for the amount and quality of gluten proteins. However, other factors, such as cropping year, site, mineral fertilization also have considerable importance (Pepó et al., 2005, Győri and Sipos, 2006, Baric et al., 2007, Drezner et al., 2007). The variation in the quality parameters originated in the glutenin subunit composition, in particular, in the balance between the high and low molecular weight subunits (Gupta et al. 1992, Tóth et al., 2006).

The extensigraph is widely used in the milling and baking industries as well as in applied basic research to classify and evaluate flours on the basis of the physical characteristics (especially the strength) of the dough. The Brabender extensigraph is one of the numerous empirical rheological equipment that measures the expansibility and the resistance to expansion of the dough after a determined period of resting time (Preston and Hoseney 1991). The analysis with the extensigraph can determine the expansibility and the resistance to expansion of the dough, on the basis of which the bread-making properties or the quality of the final product of a flour can be concluded (Bloksma 1990a,b; Hoseney 1994).

Our objective in this investigation was to study the influence of weather conditions during the growing period on extensigraph properties of winter wheat doughs.

\section{MATERIAL AND METHODS}

Samples are from the Látókép Experimental Site of The University of Debrecen, Centre of Agricultural Sciences. It has calcareous chernozem soil with a 70-90 cm deep humic layer, the humus content 2,8-3\%. The groundwater level is between 6-8 m. This soil has medium level nitrogen and phosphorous and high level potassium supplies. The $\mathrm{pH}$ measured in $\mathrm{KCl}$ is 6.2 . In the experiment we applied the following treatments: a control, $30 \mathrm{~kg} \mathrm{ha}^{-1}$ nitrogen, $22.5 \mathrm{~kg}$ ha- $1 \mathrm{P}_{2} \mathrm{O}_{5}$ and $26.5 \mathrm{~kg} \mathrm{ha}^{-1} \mathrm{~K}_{2} \mathrm{O}$ and the double, threefold, fourfold and fivefold amount of these doses in four repetitions. Five winter wheat cultivars were investigated from 2006, 2007, and 2006 harvest years.

In total, 216 flour samples were analyzed for extensigraph properties. Dough properties were determined by the Brabender Extensigraph according to Approved Method 54-10 (AACC International 2000) after a 135minute rest period.

The precipitation and temperature data of cropping years are from the Institute of Crop Sciences of the University of Debrecen.

Statistical analysis of the data was performed using SPSS 13.0 statistical software. One-way ANOVA was used to analyze data to ascertain whether the weather conditions significantly affected the rheological properties of dough. 


\section{RESULTS AND DISCUSSION}

The weather conditions were very different during the studied cropping years. As the Figure 1 shows, the least precipitation fell in 2007 , and the mean yearly rainfall was the highest in 2008 . We can say that the quantity of precipitation in 2006 was average and equal to the average of the last 30 years period.

Figure 1.: Precipitation in the studied years

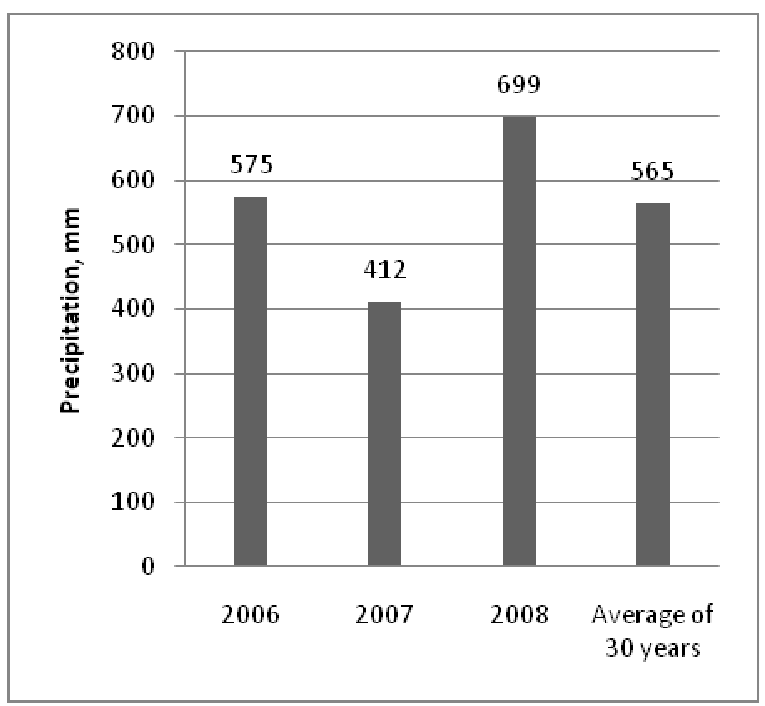

In regarding to the average temperature values of years, we determined that the 2006 cropping year was the coolest and very similar to the average of the last 30 years, but we measured $23.2{ }^{\circ} \mathrm{C}$ in July of 2006 , while this value is 20.3 by the 30 years average. The average day temperatures were higher in 2007 and 2008 as compared to the 2006 cropping year and the 30 years average. We found the biggest difference in January, February, and June. The 2007 year was the warmest and driest from the studied years, and during summer months the average day temperature was more than 22 Celsius degree (22.2, 23.3, and 22.3, respectively in June, July, and August). The winter was very mild in 2007 and 2008; the average day temperature was about $+1{ }^{\circ} \mathrm{C}$ in January and February (3.7, 4.1, and 1.0, 3.0, respectively in 2007 and 2008).

Figure 2.: Average temperature in the studied years

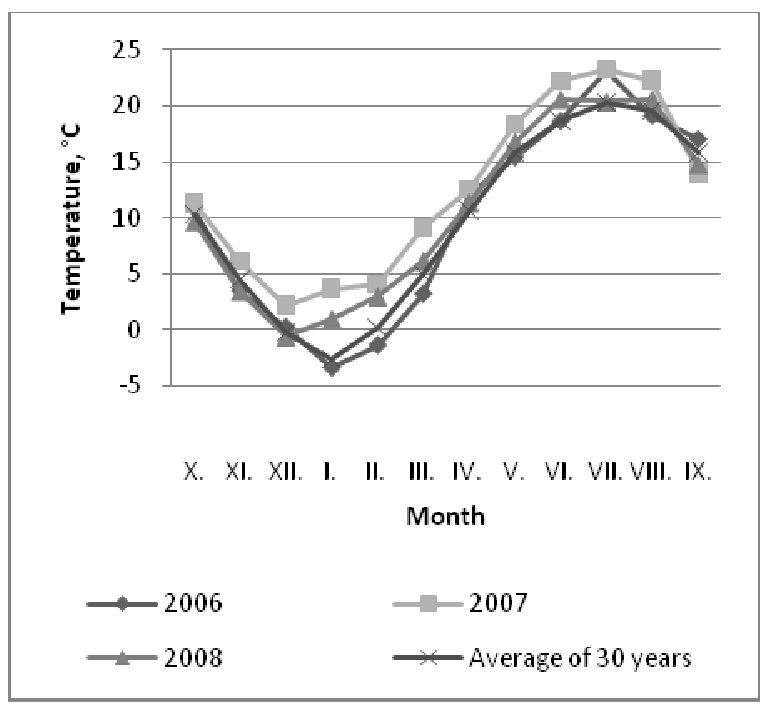


We studied the distribution of precipitation of years. We found differences between the fell precipitations during the first two months (Figure 3.), which data is important to know the weather conditions of start phase of growing of winter wheat plants. In 2006 fell the smallest quantity rain in October and November in spite of the precipitation of this year was average $(575 \mathrm{~mm})$; the distribution of precipitation was disadvantageous. The highest precipitation level was measured during this months in 2008, and moderate precipitation was in 2007 (32 $\mathrm{mm})$.

Figure 3.: Precipitation during the first two months (in October and November)

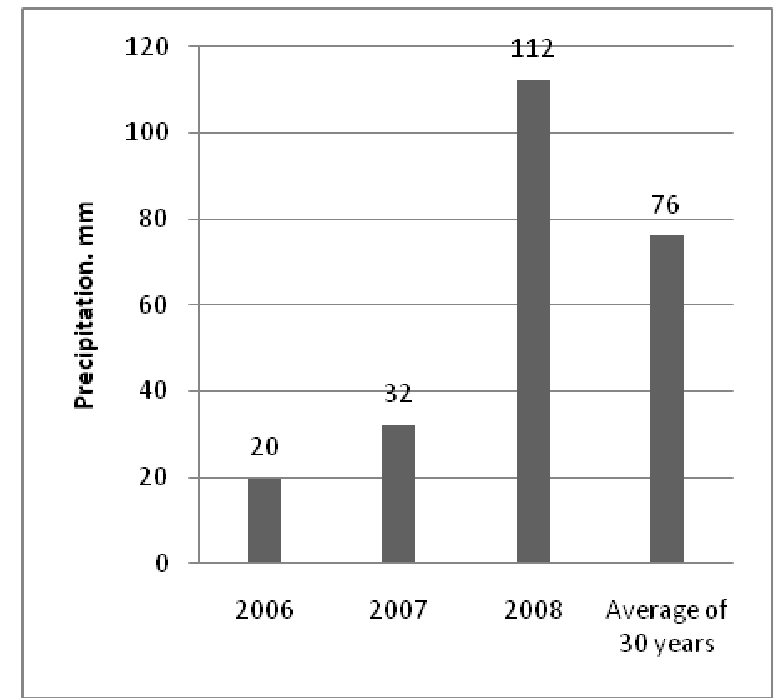

The quantity of precipitation during the whole growing period is a better parameter than the mean yearly rainfall measurement. In contrast with the previous (Figure 3), the Figure 4 show that the most precipitation was in the 2006 growing period $(399 \mathrm{~mm})$. The rainfall during the growing period was relatively low in 2007 and it was above the 30 years average in 2008 .

\section{Figure 4.: Precipitation during growing period (from October to July)}

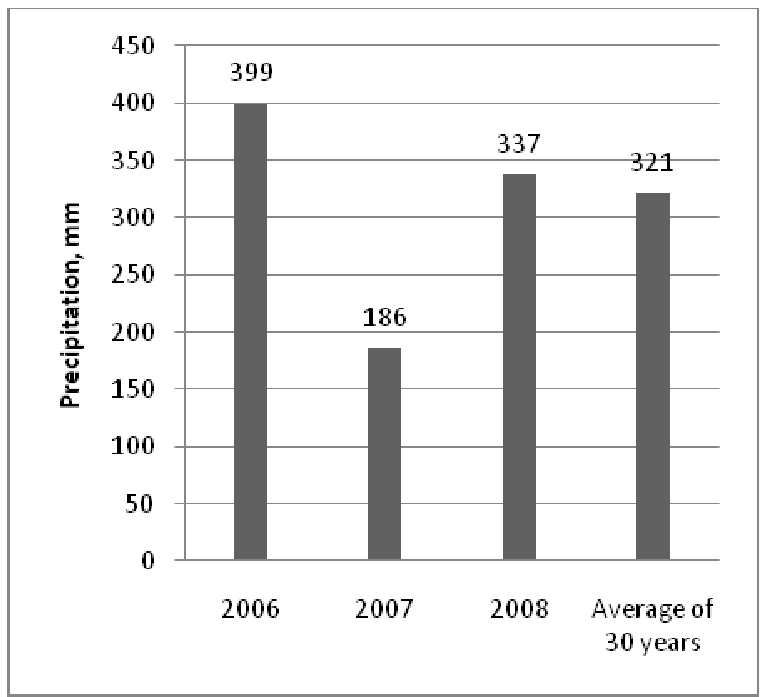

The extensigraph properties of winter wheat cultivars were affected by weather conditions during the growing period. The area under the curve is one of the most important parameter among the studied rheological parameters. The winter wheat cultivars got the highest mean area values ( $81 \mathrm{BU})$ in 2007 (Table 2.). It is very interested because this year was the droughtiest and the mean yearly temperature was the highest. In 2006, we got the worst extensigraph values (Table 1.) in order to the most rain fell in growing period of this year. The extensibility and maximum resistance parameters of doughs were the highest in 2007. 
The different weather conditions of studied cropping years affected the cultivars in different way and extent. The changed weather conditions did not affected the rheological parameters of Öthalom than Lupus or Suba. These two last mentioned cultivars improved to a great extent responded to the changed weather conditions (Table 2. and Table 3.).

Extensigraph properties of different winter wheat cultivars in $2006(n=72)$

\begin{tabular}{|c|c|c|c|c|}
\hline Cultivar & Area $\left(\mathrm{cm}^{2}\right)$ & Resistance (BU) & Extensibility (mm) & $\begin{array}{c}\text { Maximum } \\
\text { resistance (BU) }\end{array}$ \\
\hline Öthalom & 62 & 269 & 136 & 357 \\
\hline Lupus & 35 & 134 & 148 & 171 \\
\hline Saturnus & 35 & 128 & 147 & 165 \\
\hline Sixtus & 27 & 104 & 145 & 128 \\
\hline Suba & 38 & 114 & 154 & 161 \\
\hline Mean & 39 & 150 & 146 & 196 \\
\hline SD & 13.3 & 67.7 & 6.5 & 91.3 \\
\hline
\end{tabular}

Extensigraph properties of different winter wheat cultivars in $2007(n=72)$

\begin{tabular}{|c|c|c|c|c|}
\hline Cultivar & Area $\left(\mathrm{cm}^{2}\right)$ & Resistance (BU) & Extensibility (mm) & $\begin{array}{c}\text { Maximum } \\
\text { resistance (BU) }\end{array}$ \\
\hline Öthalom & 62 & 127 & 298 & 385 \\
\hline Lupus & 74 & 172 & 193 & 339 \\
\hline Saturnus & 95 & 167 & 268 & 455 \\
\hline Sixtus & 75 & 155 & 241 & 382 \\
\hline Suba & 99 & 169 & 276 & 466 \\
\hline Mean & 81 & 158 & 255 & 405 \\
\hline $\mathrm{SD}$ & 15.5 & 18.5 & 40.3 & 53.6 \\
\hline
\end{tabular}

Extensigraph properties of different winter wheat cultivars in $2008(n=72)$

\begin{tabular}{|c|c|c|c|c|}
\hline Cultivar & Area $\left(\mathrm{cm}^{2}\right)$ & Resistance (BU) & Extensibility (mm) & $\begin{array}{c}\text { Maximum } \\
\text { resistance (BU) }\end{array}$ \\
\hline Öthalom & 71 & 161 & 221 & 339 \\
\hline Lupus & 102 & 196 & 215 & 416 \\
\hline Saturnus & 67 & 169 & 190 & 308 \\
\hline Sixtus & 56 & 168 & 161 & 258 \\
\hline Suba & 87 & 188 & 201 & 359 \\
\hline Mean & 77 & 176 & 198 & 336 \\
\hline SD & 18.0 & 14.8 & 23.8 & 58.7 \\
\hline
\end{tabular}

\section{CONCLUSIONS}

Based on our examinations, we have established that the extensigraph properties of dough are affected by the weather conditions of cropping year.

The cultivars got better extensigraph values when the weather during the cropping year was warmer and the quantity of precipitation was less than the 30 years average. We determined that not only the quantity of precipitation is important but the distribution of precipitation can affect the rheological parameters of winter wheat doughs.

We have observed that various cultivars very much distinctly react to the changing the temperature and precipitation. In generally, we experienced that the higher temperature and lower precipitation level improved the quality of winter wheat flour, but we do not have any information about the yield of wheat cultivars in these cropping years.

The data presented are for a set of cultivars grown at one location in three years, it could be very interesting to continue these examinations on further cropping years and different sites. 


\section{REFERENCES}

Baric, M. - Sarcevic, H. - Keresa, S. - Habus Jercic, I. - Rukavina, I. (2007): Genotypic differences for nitrogen use efficiency in winter wheat (Triticum aestivum L.). Cereal Research Communications, 35: 213-216.

Bloksma, A. H. (1990): Rheology of the breadmaking process. Cereal Foods World 35:228-236.

Bloksma, A. H. (1990): Dough structure, dough rheology, and baking quality. Cereal Foods World 35:237-244.

Drezner, G. - Dvojkovic, K. - Horvat, D. - Novoselovic, D. - Lalic, A. (2007): Environmental impacts on wheat agronomic and quality traits. Cereal Research Communications, 35: 357-360.

Gupta, R. B. - Batey, I. L. - MacRitchie F. (1992): Relationships between protein composition and functional properties of wheat flours. Cereal Chemistry, 69: 125-131.

Győri Z. - Sipos P. (2006): Investigation of wheat quality on different samples. Buletinul USAMV-CN. Cluj-Napoca. Romania. nr. 62/2006. (Ed.: L. A. Marghitas). 258-263. ISSN 1454-2382.

Hoseney, R. C. (1994): Principles of cereal science and technology American Association of Cereal Chemistry, St. Paul. MN., U.S.A.

Pepó P. - Sipos P. - Győri Z. (2005): Effects of fertilizer application on the baking quality of winter wheat varieties in a long term experiment under continental climatic conditions in Hungary. Cereal Research Communications, 33: 825-832.

Preston, K. R., and Hoseney, R. C. (1991): Applications of the Extensigraph Hand book. F. Rasper and K. R. Preston, ed. AACC International, St. Paul, MN., U.S.A..

Tóth Á. - Sipos P. - Győri Z. (2006): A GK Öthalom és a Fatima őszi búzafajták (Triticum aestivum) alveográfos minőségének alakulása az évjárat és különös tekintettel a mütrágyázás hatására, nyolc év eredményei alapján. Növénytermelés. 55: 15-26. 